\title{
Assessment of satisfaction with hospital care in the ED and the Admissions depending on the place of living
}

\begin{abstract}
Introduction. Patient satisfaction should be a key element in the functioning of any healthcare facility. Understanding and meeting the needs of the patient on the appropriate quality level can be a "to be or not to be" for the hospital.

Aim. The aim of the study was to investigate patients' views about patient satisfaction with medical care implemented in the emergency department and the admissions of the District Hospital in Kraśnik depending on their place of residence.

Material and methods. Patients' satisfaction survey was carried out in the following two years: in January 2012 and in February 2013. The study involved 95 respondents who completed the questionnaire individually, and in case when establishing contact with the patient was not possible, family members or carers made the assessment. A tool for research was a questionnaire called "Patient satisfaction survey" designed by the nursing managers and approved by the management of the hospital.

Results. Respondents assessed the work of the Emergency Department (ED) and the Admissions well. In the first year of the study, $55.5 \%$ of patients rated the ED work very well, and the Admissions - well (58.1\%). Patients living in rural areas assessed ED very well and well (45.5\% each), and assessed the Admissions - well 48.4\%. In the next year of the study, the patients living in the city gave good ratings both to the ED department and Admissions $-41.7 \%$ and $69.45 \%$ of the patients respectively, similarly as the patients from rural areas $-46.8 \%$ and $43.2 \%$ respectively.

Conclusions. Overall rating of health services made by hospitalized patients and the availability, terms and conditions of the treatment course was very positive. The assessments of the ED and hospital Admissions were not affected by the patients' place of residence.
\end{abstract}

Keywords: patient's satisfaction, hospital emergency department (ED), hospital admissions, quality of care, urban commune, rural commune.

DOI: $10.12923 / \mathrm{j} .0044-2011 / 123-3 / \mathrm{a} .01$

\section{INTRODUCTION}

Satisfaction is commonly associated with satisfaction accompanying consumption of goods and services; hence, it is believed that there is a relationship between satisfaction and the high quality of the offered products, services. In the analysis of customer satisfaction, the relationship that exists between the subjective evaluation of the service and the client's expectations is crucial. Satisfaction arises when subjective assessment of performance is at least equal to the expectations of the customer. Thus, satisfaction of the recipient of services is a patient's emotional state, which is the result of service, and this state is directly linked to all elements of the quality of service.

In today's world where competition is widely discussed, the problem of quality has become one of the most important issues. Modern organization, irrespective of the nature of the business, should rely on quality. It is becoming the basis for successful business and it is not just a factor of success in the market, but also the determinant of culture.
Healthcare institutions are organizations for which the highest quality of service should be a priority. The quality of medical services has a direct impact on the health and life of the patient.

Patients evaluate medical service variously. This assessment is the most subjective, as it relates to the highest value, which is the health or life of the patient, and this applies in particular to emergency departments or admission rooms.

Various factors influence patients' satisfaction with health services. The most often mentioned are availability of services, reduction of waiting time for service, the course of medical visits, nursing care, health improvement. Patients' opinion is largely subjective and manifests itself in the degree of satisfaction with the realized process of diagnosis and treatment. So not caring for the specific needs of patients and their perception by the environment, poses a real danger of losing the reputation by a specific organizational unit or an entire hospital in medical services market [1].

Quality of care, willingness to recommend a medical facility or a desire to return to the same hospital by the patient,

\footnotetext{
${ }^{1}$ Independent Public Health Care in Kraśnik, Poland

${ }^{3}$ Medical University of Lublin, II Faculty of Medicine with the English Division, Department of Public Health, Poland
} 
are three unique variables, which are priorities to the patient and which affect the creation of satisfaction with the service received. In addition, patients' experiences and the level of their satisfaction are an important source of information for the hospital. Patient satisfaction surveys give an opportunity to know what patients think of the services offered by the hospital and allow for determining dysfunctions in its activities. They can also provide information about various areas of the healthcare facility operations that affect both directly and indirectly the overall hospital treatment and, consequently, contribute to the satisfaction of the patient. They help in identifying problems, solving them, and allow for the use of such solutions in a medical facility, which will aim at improving the quality of its operation [2].

The word "satisfaction" in Latin satis, means "enough" or as much as needed to meet fully the expectations, needs, aspirations, so that no space is left for the complaint.

Satisfaction of the patient - recipient of services is a subjective sense of satisfaction associated with personal experiences, expectations, and values, while for the doctor, nurse - the service providers, the quality is objectively a certain degree of compatibility of the provided service with the professional knowledge and standard of care [3].

Patient satisfaction survey of hospital stay is a common method of assessing the quality of health care. It is a valuable way to prevent iatrogenic errors, mistakes, to verify the quality of medical services. Thanks to these assessments, the therapeutic team obtains information on the level of care exercised by them, meets the needs and expectations of patients, which helps in solving their problems.

\section{AIM}

The aim of the study was to investigate patients' opinions about their level of satisfaction with medical care undertaken in the hospital emergency department (ED) and hospital admissions room in District Hospital in Kraśnik depending on their place of residence.

\section{MATERIAL AND METHODS}

Patient satisfaction survey was carried out in the Autonomous Public Health Care Unit in Kraśnik in the subsequent two years: in January 2012 and in February 2013. The survey tested patients' satisfaction with service delivery in the admissions room and ED - 40 respondents in 2012 and 45 in 2013. The respondents completed the questionnaire individually and in case when establishing contact with the patient was not possible, family members or carers made the assessment.

The tool for research was a questionnaire called "Patient satisfaction survey" designed by the nursing managers and approved by the management of the hospital.

The questionnaire survey for assessing the satisfaction consisted of 7 questions on demographics and 29 specific questions divided into six thematic blocks. These were the admission to hospital ED/Admissions, the rooms in the ED/Admissions, nursing care, diagnostics, environment, doctors.
Among the town residents surveyed in 2012 in the ED, women constituted a more numerous group (60\%). They were mainly patients in the third decade of life, with an average age of 36.6. For those patients it was the first stay or a subsequent stay in the hospital, and the average hospital stay was 5.6 days. Emergency department patients coming from rural areas were persons equally distributed, for whom this was the first and subsequent stay in the hospital equally for men and women. The average stay was 12 days and the median age of hospitalized was 46.5 years.

Patients in the Admissions in 55.6\% were people living in the city, aged 56.9 years, for whom in $50 \%$ it was a subsequent hospitalization, of which $80 \%$ were women. The median time of the last hospital stay was 6.3 days for these people.

Patients living in rural areas, reporting to the Admissions were previously hospitalized in a hospital in $62.5 \%$ and the average time of the last hospital stay was 9.1 days. They were mainly patients in the fifth decade of life (mean age 58.7 ), most of them women $-75 \%$.

The respondents surveyed in 2013 accounted for 55.9\% of ED patients and 44.1\% -of the Admissions.

Patients for whom medical treatment was implemented in the ED - the inhabitants of the city - were mainly people aged $30-50$ years (mean 43.4), mostly women (78.9\%). The duration of last hospital stay was on the average 3.7 days and for $62.5 \%$ of patients, this was the first stay in the hospital.

In the hospital Admissions, however the majority were women $(90 \%)$. Most of the patients $(80 \%)$ were hospitalized once again for an average period of six days. The average age of those patients was 55 years.

More than half of people living in rural areas being the patients of ED $(66.7 \%)$ once again stayed in hospital with duration of stay of 2 days. Mean age was 40 years, and they were equally men and women (50\%).

In the Admissions, the majority were women (60\%), too. Hospitalization lasted on average seven days, and was the repeated one for $60 \%$ of patients. The mean age of patients was 60 years, with the largest group of patients in the 6th and 7 th decade of life.

\section{RESULTS}

The study of patient satisfaction with hospital stay is a common way to assess the quality of healthcare. It is an extremely valuable way to verify the quality of medical services. Patient satisfaction survey allows identification of what in the field of medical services is a source of patient dissatisfaction; on the other hand, the fulfillment of which expectations and requirements of the patient (in addition to the recovery or the health improvement after leaving the hospital) is a condition for perception of services as high quality ones.

ED patients in the first thematic block containing two questions assessed the formalities connected with the Admissions in the ED. Both the ease of getting into the hospital, as well as the rate of settling formalities the patients - town-dwellers in 2012 rated very well. Such ratings ranged from $64.3-73.3 \%$, good ratings reached a value of $20-28.6 \%$, 
and satisfactory ratings accounted for $7 \%$. People living in rural areas gave to these issues a very good and good rating $(50 \%)$, which was repeated in another study of 2013. However, patients who lived in the city in 2013 rated the procedures related to admission well with $5 \%$ satisfactory ratings.

The patients from rural areas admitted in 2012 evaluated the formalities connected with admission very well. Every eight patient gave a satisfactory grade for the ease of getting to the hospital, while a year later - every 4th patient, with the overall good assessment.

Patients from the city assessed the issue in the first year of the survey in $50 \%$ - very well and well, and a year later well. In both years, $10 \%$ of patients gave a satisfactory grade for the speed of completion of formalities.

The second thematic block of questions consisted of five questions describing the rooms of the studied organizational units.

The respondents living in the villages in $50 \%$ evaluated this module very well and well in 2012, and the inhabitants of the city - very well. A good rating given by $46.2 \%$ of patients from city referred to the noise. Every fourth respondent gave a satisfactory rating, and in equal amounts - patients from the city expressed in $7.7 \%$ bad and very bad ratings. Respondents pointed to the unfulfilled expectations of their room equipment, which is reflected in the satisfactory assessments $-13.4 \%$ (town residents) and bad $-25 \%$ (rural residents). Overall rating of cleaning staff was very good and good.

Residents of villages in 2013 gave assessment similar to those of the previous year; lowering of ratings given by city residents for the room equipment, noise, the temperature in the room, from very good to good are worth noting. Furthermore, every 10th patient sufficiently evaluated the cleanliness and temperature in the rooms, and every fifth - the equipment. Patients living in the countryside gave sufficient ratings for temperature in the rooms (every 3rd respondent) and cleaning staff (every 10th ) and a low ratings for the facilities (every 10th patient).

Respondents reporting to the Admissions (from both the town and the village) in both years evaluated well the state of the facilities and the villagers gave very good ratings to cleaning staff.

In the next module, which contained six questions, the respondents evaluated the work of nurses.

Patients from ED residing in the town in both studies (in 2012 and 2013) evaluated the nursing care very well, whereas $5 \%$ of satisfactory ratings were recorded. Patients from rural areas expressed an improvement in the work of nurses in relation to the previous study from a very good and good to very good. However, in 2013 every 10th patient gave a satisfactory grade (not expressed in the previous year) to the promptness of response to calls and requests and the provision of information and explanations.

In 2012 the Admissions patients residing in rural areas evaluated nurses' work very well, and the promptness of response to the call and the provision of information - well, while in the following year all the issues were rated very well. Patients from the city in both studies gave very good and good assessments on nursing care (kindness, responses to requests, availability at night), while every 10th patient gave satisfactory rating for the same issues that were rated very well.

The fourth thematic block concerned the diagnosis, in which deterioration was noted in 2013 in the evaluation of ED by country dwellers, assessing the way of performing examinations, the waiting time for the examinations and the behavior of the employees as good, while a year earlier - very good and good ( $50 \%$ each). In addition, every fifth patient rated satisfactorily the waiting time for the examination. Patients residing in the city expressed similar assessments - there was a lowering from very good to good while $15.8 \%$ of patients rated waiting time for the examination satisfactorily.

Respondents from the city rated the process of diagnosing patients in the ED in both years of the survey well. It is worth noting $30 \%$ of satisfactory ratings in 2013 for waiting time for examination and in $2012-20 \%$ satisfactory notes for the courtesy of the staff, $10 \%$ poor ratings for waiting time for examination and $10 \%$ of very poor ratings for the manner of carrying out the examination. Patients from rural areas commented on the diagnostics well (2012) and very well (2013), simultaneously giving satisfactory ratings for the long waiting period for the examination, in each year, respectively $-37.5 \%$ and $25 \%$.

Patients from ED gave negative ratings for hospital environment, such as the availability of parking and the store. For these matters, there were given satisfactory and poor $(20 \%$ each) or very bad ratings $(60 \%)$.

The admissions patients gave similar assessments, negatively evaluating the possibility of using the store or parking.

The last of the evaluable aspects was the work of doctors. Residents of rural areas, who were offered medical care at ED in 2012 gave a good mark to physicians and at the same time every 4 th patient rated doctors' kindness and availability in the afternoon and night satisfactorily. Patients from the city also gave overall good assessment, and for time devoted to the patient - very good, while $40 \%$ assessed it satisfactorily. Furthermore, a large proportion of the overall of satisfactory ratings $(20-26.7 \%)$ was registered.

All patients evaluated the work of Admissions doctors well. Every eighth resident of the village in 2012 gave a bad rating for the kindness and information provision, and for the availability at nighttime - very bad rating; in 2013 the respondents gave satisfactory ratings for availability in the afternoon and at night, and for the kindness at $40 \%$ each. Patients from the city in 2012 rated very poorly (every 10th patient) and satisfactorily (20\%), the kindness of doctors, the time devoted to the patient and availability at night as while a year later, these evaluations completely improved and only $10 \%$ of respondents rated the availability of doctors in the afternoon and night satisfactorily.

Patients of Admissions and ED gave these departments the overall good rating, with declining trend in 2013. A detailed review of the evaluations is presented in Table 1. 
TABLE 1. A detailed review of the ratings given to Emergency and Admissions Departments, issued by the patients.

\begin{tabular}{|c|c|c|c|c|}
\hline Year & $\mathrm{T} / \mathrm{V}$ & Rating (\%) & $\begin{array}{c}\text { Hospital Emergency } \\
\text { Department }\end{array}$ & Admissions \\
\hline \multirow{10}{*}{$\frac{\text { ก }}{2}$} & \multirow{5}{*}{$\overbrace{0}^{0}$} & Very good & 55.5 & 24.3 \\
\hline & & Good & 28.4 & 58.1 \\
\hline & & Satisfactory & 12.9 & 10.9 \\
\hline & & $\mathrm{Bad}$ & 1,9 & 4,4 \\
\hline & & Very bad & 1,3 & 2,3 \\
\hline & \multirow{5}{*}{ 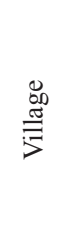 } & Very good & 45.5 & 38.4 \\
\hline & & Good & 45.5 & 48.4 \\
\hline & & Satisfactory & 4.5 & 6.9 \\
\hline & & $\mathrm{Bad}$ & 4.5 & 5.2 \\
\hline & & Very bad & - & 1.1 \\
\hline \multirow{10}{*}{$\stackrel{m}{\stackrel{\pi}{\Gamma}}$} & \multirow{5}{*}{ 㿣 } & Very good & 38.8 & 19.2 \\
\hline & & Good & 41.7 & 69.4 \\
\hline & & Satisfactory & 11.8 & 6.4 \\
\hline & & $\mathrm{Bad}$ & 3.1 & 5 \\
\hline & & Very bad & 4.6 & - \\
\hline & \multirow{5}{*}{ 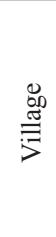 } & Very good & 39.1 & 39.1 \\
\hline & & Good & 46.8 & 43.2 \\
\hline & & Satisfactory & 8.6 & 12.3 \\
\hline & & $\mathrm{Bad}$ & 2.3 & 4.5 \\
\hline & & Very bad & 3.2 & 0.9 \\
\hline
\end{tabular}

\section{DISCUSSION}

Research carried out in Autonomous Health Care Unit in Kraśnik over two consecutive years indicates high patient satisfaction with medical services provided by the organizational units of the hospital with which the patient comes into contact in the first instance, i.e. Admissions or ED. This applies both to the overall assessment of the services provided by these departments, as well as the conditions and the course of treatment and satisfaction with access to a doctor and other hospital staff.

Similar results were also obtained in studies conducted in other centers across the country.

One of them was a study undertaken at the School of Public Health of Postgraduate Medical Center in collaboration with the Mazowieckie Regional Centre of Public Health and the Department of Health Promotion and Postgraduate Education of National Institute of Public Health - NIH. The study randomly selected six hospitals from the "Register of healthcare facilities in the Mazowieckie Province" - two hospitals were located in Warsaw, the other three in other cities located in the Mazowieckie Province.

The conditions of hospital treatment were assessed positively. Three-quarters of patients said they waited short for admission to the hospital, and only one patient out of ten rated waiting time for the admission to the hospital as long. Most patients did not wait in the Admissions or decided that the waiting time was short. However, every seventh patient waited on average long and every sixteenth rated waiting as long. It should be noted that patients whose stay in hospital was planned, waited on average for almost two months for the admission to the hospital (50 days), and some of them even a year. However, in the Admissions patients were waiting approximately for 40 minutes and $44 \%$ of patients - up to 15 minutes and more than an hour $-13 \%$, including $5 \%$ waiting for more than two hours [4] .

Research carried out in a hospital admissions in Brzeziny in 2004 showed that the opinions of those living in the countryside on the time of completion of formalities in the admissions, in all assessments was slightly better than in the opinions issued by the city residents. Similarly, the opinions of women in all assessments were slightly better than the opinions of men. The most critical in their opinions were patients over 50 years of age, and the best evaluations were given by patients aged between 30 and 50 years of age.

Patients' opinions regarding the courtesy of the staff nurses were the same as for the previous issue when it comes to the relationship between the place of residence, gender, or age [5].

Comparative study of patient satisfaction with the functioning of hospital Admissions in Brzeziny was conducted in 1999 and 2004. In 1999, 2.9\% of the patients negatively rated the duration of formalities in the admissions, satisfactory evaluation was given by $16.7 \%$, good - by $43.2 \%$ and very good - by $37.2 \%$ of respondents. In 2004 , the negative evaluations were given by $2.6 \%$ of the patients, satisfactory - by $13.9 \%$, good - by $44.7 \%$ and very good by $38.8 \%$ of respondents. In 1999 , the negative ratings concerning politeness the nursing staff in the admissions were given by $3.7 \%$ of the patients, satisfactory - by $18.6 \%$, good - by $47.5 \%$, and very good - by $30.2 \%$ of respondents. In $2004,2.4 \%$ of the patients rated negatively politeness of nursing staff in the admissions. Satisfactory assessment was given by $13.7 \%$ of people, good - by $48.4 \%$, and a very good - by $35.5 \%$ of respondents. Given assessments by patients in 1999 were less favorable than assessments made by patients in 2004 [6].

The study of patient satisfaction with nursing care was conducted in two emergency departments in Gdansk in Clinical Emergency Department (KOR) in the University Clinical Center and Hospital Emergency Department (ED) at St. Wojciech Specialist Hospital between 2005-2007 and 2009-2010. Patients highly evaluated the nursing care - in the KOR at 130 points in 156 possible, and in the ED at 82 points. Total score in both departments exceeded $50 \%$ of the maximum, indicating, according to the authors, patients' satisfaction with nursing care. Patients assessed the following aspects according to a 6-point scale: interpersonal communication (KOR - 5.23, ED - 4.47), education (KOR - 5.20, ED - 3.42) caring tasks (KOR-4.96, ED- 2.91), compliance with the guidelines (KOR - 4.97; ED -1.94), ensuring privacy (KOR $-5.20, \mathrm{ED}-4.19)$, interdisciplinary team collaboration (KOR - 5.34, ED -3.34), emotional support (KOR - 4.69, ED - 2.63) creation of a relaxing atmosphere (KOR - 4.99, ED - 4.01), the time devoted to subjects (KOR - 5.16, ED - 4:19). In addition, patients found that satisfaction level is influenced by waiting too long for diagnosis (KOR - 46.23\% ED - 53.77\%), too few staff nurses (KOR $-14.14 \%$; ED - 59.30\%), not enough space in the observation room (need to perform renovation) - KOR $-20.72 \%$, $\mathrm{ED}-26.63 \%[7]$. 
A study conducted in the Hospital Emergency Department, University Hospital No. 1, Medical University of Lodz consisted of four thematic blocks concerning interpersonal skills of doctors, work of doctors, the effectiveness of visits and general information on the approach to the patient, waiting for an appointment, providing information, nursing care. Of the respondents, $82 \%$ considered that the doctor was referring to the patient with respect, and only $2 \%$ expressed negative ratings. The interest shown by the doctor was rated positively by $77 \%$ of patients.

Giving opinions about the work of the doctor, $64 \%$ of respondents considered the provision of information about the health problem as good ( $2 \%$ of negative opinions), while tests ordered by doctors were evaluated by $70 \%$ respondents very well. Duration of visit was rated by $81 \%$ of respondents without reservation, while waiting for the results of the test was rated positively by $42 \%$ of patients and by $22 \%$ negatively.

The effects of a visit were rated by $60 \%$ of respondents positively by stating that their health condition has improved.

Respondents said that the waiting time in the ED waiting room was adequate $(74 \%)$, while $16 \%$ gave a negative response. Nursing care by $82 \%$ of respondents was rated very well, $2 \%$ indicated a negative response [8].

Global reports of satisfaction surveys of patients in emergency departments allow concluding a high patient satisfaction with medical services.

A study conducted at the Royal Hospital in Melbourne has shown that after the organizational changes in the emergency department the involvement in patient, the method of informing the patient and the overall evaluation of the department have improved There has been a reduction in the number of complaints of patients for the work of the department by $22.5 \%$ [9].

Evaluation of patient satisfaction with emergency department operation of Imam Reza Hospital in the Tabriz in Iran showed that the highest levels of satisfaction were observed in the communication between doctors and the patients $(82.5 \%)$, politeness $(78.3 \%)$ and nurses communication with patients $(78 \%)$. The average waiting time for the first visit to the doctor was 24 minutes 15 seconds. Overall satisfaction rate depended on the average waiting time. Low levels of satisfaction were recorded with the time of waiting 47 minutes 11 seconds, a very good level of satisfaction was recorded for the time of $14 \mathrm{~min} 57 \mathrm{~s}$. Approximately 63\% of patients rated overall satisfaction with emergency department work as good or very good [10].

A study conducted in the emergency department in the Moroccan university hospital showed that $66 \%$ of respondents were satisfied with the overall care, and $69.8 \%$ would come back to the unit. Most patients reported problems with the waiting time and tests results. Factors associated with lower satisfaction were distant place of residence from the hospital $(>10 \mathrm{~km})$ and education (patients with primary education and illiterate were less satisfied with care compared with patients with a high level of education) [11].

Satisfaction survey conducted in the emergency department of the university hospital in Nebraska in the USA showed that for patients or persons accompanying them in determining satisfaction with care more important were technically efficient medical activities than the timeliness and availability of bedside care [12].

\section{CONCLUSIONS}

1. Both the overall evaluation of medical services made by hospitalized patients and the availability, terms and conditions and the course of treatment were very positive.

2. Despite the high ratings of medical services, relatively high proportion of patients who perceived waiting time for admission to hospital or waiting in the Admissions as a medium length or long or did not always understand communication of health information, may raise concerns.

3. The assessments of the emergency department and hospital admissions were not affected by the patient's place of residence.

\section{REFERENCES}

1. Kautsch M, Klich J. Jakość zarządzania zakładami opieki zdrowotnej. Org Kierow. 2004;116:91-106.

2. Banaszewska A. Jak badać satysfakcję pacjentów. Sł Zdr. 2000;4-5:10-7.

3. Lenartowicz H. Zarządzanie jakością w pielęgniarstwie. Warszawa; CEM; 1998.

4. Miller M, Supranowicz P, Gębska-Kuczerowska A. Car J. Ocena jakości usług medycznych przez pacjentów szpitali. Przegl Epidemiol. 2008;62:643-50.

5. Krakowiak J, Kocemba W, Stelmach W, et al. Opinie pacjentów dotyczące szpitalnej izby przyjęć Szpitala Powiatowego w Brzezinach w 2004 roku przy uwzględnieniu czynników socjalno-demograficznych. In: J. Krakowiak, A. Marjański (ed). Problemy organizacji i zarządzania w ochronie zdrowia. Ocena i zachowanie świadczeniobiorców usług medycznych. Przedsięb Zarządz. 2010;XI(7):101-10.

6. Krakowiak J, Kocemba W, Marjański A, et al. Szpitalna izba przyjęć w opinii pacjentów hospitalizowanych w Szpitalu Powiatowym w Brzezinach w 1999 i 2004 roku. In: J. Krakowiak, A. Marjański (ed). Problemy organizacji i zarządzania w ochronie zdrowia. Ocena i zachowanie świadczeniobiorców usług medycznych. Przedsięb Zarządz. 2010;XI(7):111-8.

7. Małecka-Dubiela A. Ocena satysfakcji chorego z opieki pielęgniarskiej w Klinicznym Oddziale Ratunkowym. Gdański Uniwersytet Medyczny, Wydział Nauk o Zdrowiu z Oddziałem Pielęgniarstwa i Instytutem Medycyny Morskiej. Gdańsk; 2012.

8. Kisiel Ż, Samborska-Sablik A, Gaszyński W. Ocena jakości opieki medycznej na przykładzie Szpitalnego Oddziału Ratunkowego Uniwersyteckiego Szpitala Klinicznego nr 1 Uniwersytetu Medycznego w Lodzi. Zdr Publ. 2008;118(3):329-33.

9. Taylor D, Kennedy MP, Virtue E, McDonald G. A multifaceted intervention improves patient satisfaction and perceptions of emergency department care. Int J Qual Health Care. 2006;18(3):238-45.

10. Soleimanpour H, Gholipouri C, Salarilak S, et al. Emergency department patient satisfaction survey in Imam Reza Hospital, Tabriz, Iran. Int J Emerg Med. 2011;04:02.

11. Damghi N, Belayachi J, Armel B, et al. Patient satisfaction in a Moroccan emergency department. Arch Int Med. 2013;6(1):20.

12. Rhee KJ, Bird J. Perceptions and satisfaction with emergency department care. J Emerg Med. 1996;14(6):679-83.

Informacje o Autorach

Dr n. med MAREK Kos - p.o. Dyrektora SPZOZ w Kraśniku; mgr Agnieszka Dziewa - Naczelna Pielęgniarka SPZOZ w Kraśniku; dr n. med. BartŁomiej Drop - adiunkt, Katedra i Zakład Zdrowia Publicznego, II Wydział Lekarski z Oddziałem Anglojęzycznym, Uniwersytet Medyczny w Lublinie.

\section{Corresponding Author}

Dr Marek Kos

ul. Chopina 13, 23-200 Kraśnik

tel. 695-330-700

E-mail: marekkos@op.pl 